\title{
PENGEMBANGAN SISTEM REPLIKASI DAN REDUNDANSI UNTUK MENINGKATKAN KEHANDALAN BASISDATA MYSQL
}

\author{
Dolly Simon Kristian ${ }^{1)}$, Adian Fatchur Rochim ${ }^{2)}$, Eko Didik Widianto ${ }^{2)}$ \\ Program Studi Sistem Komputer, Fakultas Teknik, Universitas Diponegoro, \\ Jln. Prof. Sudharto, Tembalang, Semarang, Indonesia \\ email : dolly23.dk@gmail.com
}

\begin{abstract}
With the development of information technology, humans make it easy to complete every duty. Any information about the work carried out to be very valuable, therefore the information should be stored properly, by organizing a reliable database system when performing data storage on the server information. Build a design application virtualization master slave database servers that are connected with the management node using the virtual application to get the test results replication system performance and redundancy in the design of the cluster system.

Methodology of this research include the study of literature, collecting data by interview, observation, literature studies, system design, and testing of the system. In a literature study on the use of research methods to study the literature books, records that can be used as a support in the research. The design of this thesis using MySQL Cluster system with Ndbcluster engine. Last is testing this system on its performance on the server failure or failures occur and reliability in performance.

The results obtained are when there is a failure on the primary server, it will be immediately replaced by another server is a slave. And the replication of data between the main server and slave.
\end{abstract}

Keywords : database, replication, MySQL Cluster, high availability, high scalability

\section{PENDAHULUAN}

Basisdata (database) adalah kumpulan informasi yang disimpan di dalam komputer secara sistematik sehingga dapat diperiksa menggunakan suatu program komputer untuk memperoleh informasi dari basisdata tersebut. Konsep dasar dari basisdata adalah kumpulan dari uraian data. Basisdata memiliki penjelasan terstruktur dari jenis data yang tersimpan di dalamnya, atau disebut skema. Skema menggambarkan obyek yang mewakilkan suatu basisdata, serta hubungan di antara obyek tersebut. ${ }^{[1]}$

Replikasi memiliki pengertian sebagai suatu proses perpindahan data dari suatu basisdata (master) ke basisdata (slave) lain yang tersimpan pada komputer yang berbeda. Untuk melakukan proses replikasi dibutuhkan dua buah komputer atau lebih yang berfungsi sebagai server dengan satu server sebagai master dan yang satu sebagai slave. Dengan replikasi, data dapat didistribusikan ke lokasi yang berbeda dan pengguna yang jauh melalui LAN, WAN, Dial-up Connection, wireless connections, dan internet.

Tujuan penelitian ini adalah bertujuan untuk membangun sebuah rancangan virtualisasi aplikasi server master slave basisdata yang terhubung atau terkoneksi dengan manajemen node dan slave basisdata, menggunakan aplikasi VirtualBox untuk mendapatkan hasil uji performa sistem replikasi dan redudansi dalam rancangan sistem kluster.

Pembuatan basisdata kluster ini dilatarbelakangi oleh manfaat replikasi basisdata untuk menghindari kemungkinan tidak semua data tersalin karena saat proses penyalinan data manual dilakukan bisa saja terjadi perubahan data oleh klien. Apabila basisdata master mengalami kerusakan, basisdata bisa segera dialihkan ke basisdata slave. Replikasi master-slave berlangsung secara realtime dimana setiap perubahan pada data basisdata master akan otomatis merubah data pada basisdata slave.

\section{METODE PENELITIAN}

Tahapan-tahapan yang dilakukan dalam perancangan basisdata kluster ini adalah dengan menginstal virtualbox, kemudian membuat beberapa server pada virtualbox dengan Ubuntu Server 12.04 sebagai sistem operasinya, pembuatan mesin haproxy dengan menginstal haproxy dan apache, penginstalan wordpress dan lamp, penginstalan mysql cluster pada server node A dan node $\mathrm{B}$, penginstalan httperf sebagai aplikasi untuk pengujian ketahanan server.

Virtualisasi jaringan ini menggunakan aplikasi VirtualBox. Oracle VM VirtualBox adalah perangkat lunak virtualisasi yang dapat digunakan untuk mengeksekusi sistem operasi tambahan di dalam sistem operasi utama. Melakukan penginstalan virtualbox sebagai langkah pertamayang dilakukan.

Pembuatan server pada mesin virtual dengan menggunakan Ubuntu Server 12.04 sebagai sistem operasi tiap-tiap server. Server Host menggunakan ubuntu server sebagai sistem operasi. Ubuntu server versi saat ini adalah Ubuntu 12.04 Long Term Support (LTS) release, yang akan didukung hingga 2017.

Pembuatan mesin HAproxy dengan melakukan penginstalan Haproxy 1.4 terhadap salah satu server yang telah dibuat. ${ }^{[10]}$ 
Pembuatan server aplikasi dengan penginstalan wordpress sebagai media untuk menguji apakah basisdata kluster yang dirancang dapat digunakan oleh aplikasi CMS. WordPress adalah sebuah aplikasi sumber terbuka (open source) yang digunakan sebagai CMS (Content Management System) pada situs web. Wordpress menggunakan bahasa php dan menggunakan MySQL sebagai basisdatanya. ${ }^{[4]}$

Penginstalan MySQL pada server untuk menjadikan server tersebut sebagai Node A dan Node B yang berkerja dengan mesin kluster.MySQL merupakan perangkat lunak untuk manajemen basisdata dan sebagai tempat penyimpanan data pada server aplikasi. Pada sistem di sini menggunakan mysql-kluster-gpl-7.3.7-linuxglibc2.5-x86_64.tar yang basisdatanya direplikasi satu arah master to slave. ${ }^{[5]}$

Penginstalan LAMP pada server aplikasi untuk mendukung kinerja server dalam menampilkan aplikasi yang telah tertanam dalam server. $L A M P$ adalah sebuah aplikasi web server Apache yang di dalamnya sudah tersedia database server MySQL dan support php programming. Komponen LAMP yaitu Apache, PHP, MySQL dan phpMyAdmin. LAMP merupakan aplikasi yang mudah digunakan, gratis dan mendukung instalasi di Linux dan Windows. Keuntungan lainnya adalah cuma menginstal satu kali sudah tersedia Apache Web Server, MySQL Database Server, PHP Support (PHP 4 dan PHP 5) dan beberapa modul lainnya.

Penginstalan httperf sebagai aplikasi yang digunakan untuk mengukur ketahanan suatu server. Httperf adalah program untuk mengukur kinerja atau performansi dari web server yang dibuat oleh David Mosberger dari HP Labs. Httperf menyediakan fitur yang fleksibel dalam pembuatan beban kerja sesuai dengan parameter yang diberikan padanya. Httperf merupakan sebuah aplikasi untuk sistem operasi turunan UNIX. Httperf dapat membangkitkan sejumlah beban paket dan mendukung HTTP/1.0 dan HTTP/1.1. Httperf dalam mengukur performansi sebuah web server adalah dengan mengirimkan permintaan atau paket ke server dengan rata tertentu dan mengukur waktu balasan yang diterima.

\section{PERANCANGAN DAN IMPLEMENTASI}

Sistem dirancang dengan menggunakan topologi jaringan, pada gambar 1 dijelaskan hubungan unsur dasar penyusun jaringan.

Berdasarkan topologi jaringan pada gambar 1 menjelaskan bahwa terdapat satu penyeimbang beban dengan nama HAProxy, satu server untuk aplikasi diberi nama ServerApp, dua server basisdata dengan nama DB Master dan DB Slave, satu PC untuk monitoring dengan nama NDB_MGM dan dua klien diberi nama client dan benchmark tester.

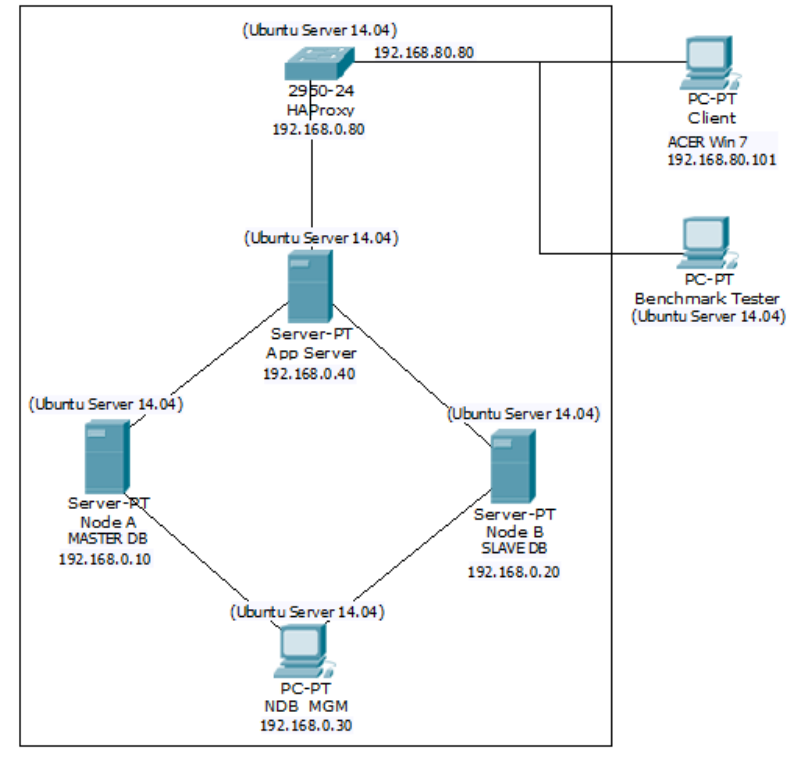

Gambar 1 Topologi Sistem

Server basisdata kluster digunakan untuk menyimpan data klien atau data yang akan digunakan oleh wordpress seperti user name dan password. Server basidata yang digunakan pada penelitian ini adalah mysql-klustergpl-7.3.7-linux-glibc2.5-x86_64.tar membuat replikasi satu arah, yaitu master to slave. ${ }^{[5]}$

Konfigurasi basisdata yang dibuat dalam konfigurasi Node adalah dengan membuat file my.cnf pada Node sebagai berikut:

\# nano/etc/my.cnf

Untuk tiap data node dan sql node yang kita buat, my.cnf harus terlihat dan berisi pengaturan seperti ini:

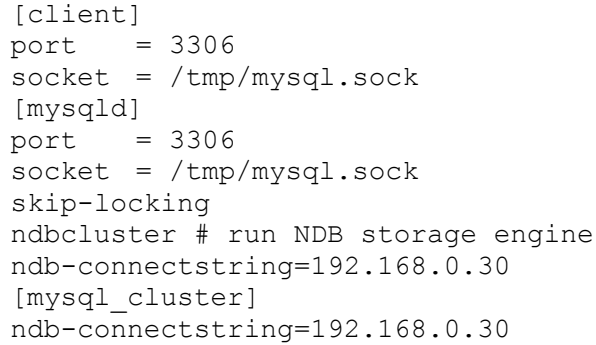

Konfigurasi manajemen node adalah untuk membuat direktori yang mana file konfigurasinya dapat ditemukan dan kemudian dapat membuat file itu sendiri.

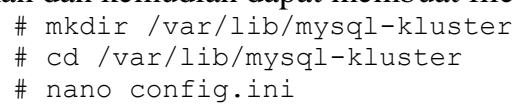

Untuk pengaturan yang kita buat, file config.ini harus dibuat seperti ini: [ndbd default] NoOfReplicas $=2$ DataMemory $=80 \mathrm{M}$ IndexMemory $=18 \mathrm{M}$ [tcp default] [ndb mgmd] host $\bar{n}$ ame=192.168.0.30 \# Hostname or IP address of MGM node 
datadir=/var/lib/mysql-kluster

Directory for MGM node log files

[ndbd]

hostname=192.168.0.10 \# Hostname or IP

address

datadir=/usr/local/mysql/data

Directory for this data node's data files

[ndbd]

hostname $=192.168 .0 .20$ \# Hostname or IP address

datadir=/usr/local/mysql/data

Directory for this data node's data files [mysqld]

hostname $=192.168 .0 .10$ \# Hostname or IP address

[mysqld]

hostname $=192.168 .0 .20 \#$ Hostname or IP address

Perangkat lunak Wordpress dipasang dikedua server aplikasi Server App. Sebelum melakukan instalasi, terlebih dahulu membuat user dan basisdata pada mysql untuk data Wordpress. Terdapat pada /wordpress/wpconfig.

\section{PENGUJIAN DAN ANALISIS}

Pembuatan deployment diagram ini bertujuan untuk memudahkan kita dalam membaca topologi yang dibangun serta aplikasi apa saja yang terdapat pada sisi server, semua tergambar jelas dalam gambar 2 .

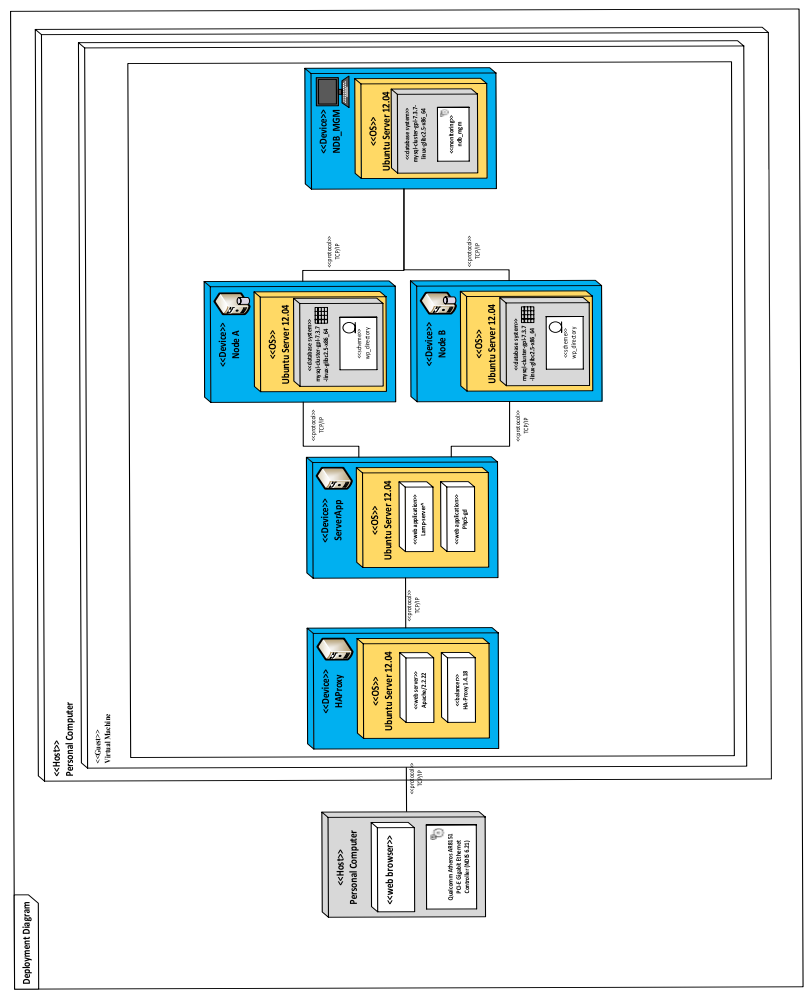

Gambar 2 Deployment Diagram

Aplikasi Wordpress telah terpasang dan telah dilakukan konfigurasi yang diperlukan pada bab sebelumnya.
* Tahapan selanjutnya adalah melakukan pengujian pada konfigurasi yang telah dibuat, apakah konfigurasi sudah benar atau masih ada error pada pelaksanaan pengujian wordpress. Pengujian dilakukan dengan cara klien mengakses ke server yang masih berada dalam localhost utnuk mencobaapakah wordpress sudah terpasang dengan benar. Wordpress diakses oleh klien dengan menuliskan alamat IP server aplikasi pada browser, seperti 192.168.0.40/wp-admin. Seperti yang di tunjukkan pada gambar 3. ${ }^{[4]}$

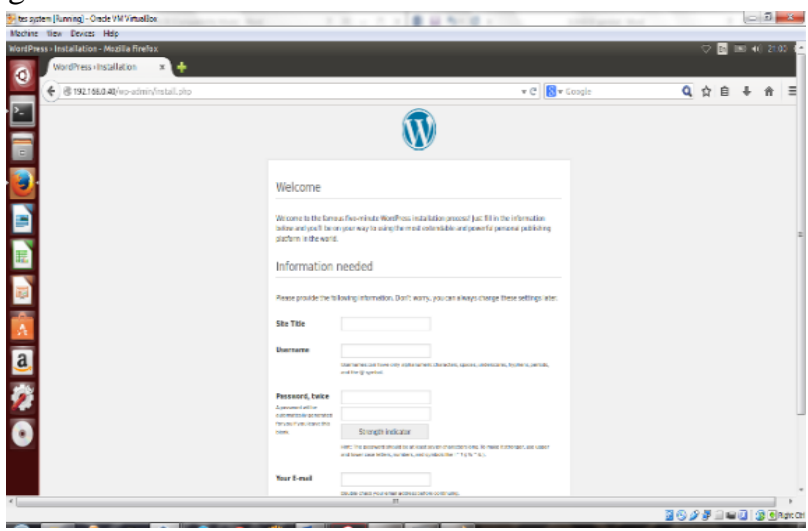

Gambar 3 Tampilan 192.168.0.40/wp-admin

Wordpress telah diinstalasi tetapi data yang disimpan masih berada di localhost. Basisdata yang sudah terbentuk oleh wordpress dipindahkan ke server basisdata MySQL yang berada pada alamat 192.168.0.10 dan 192.168.0.20.

Migrasi basisdata yang sudah dilakukan akan diuji melalui klien yang terhubung oleh server HAProxy, artinya klien tidak akan lagi melakukan uji coba permintaan melalui server aplikasi secara langsung tetapi melewati server HAProxy dahulu pada alamat 192.168.80.80.

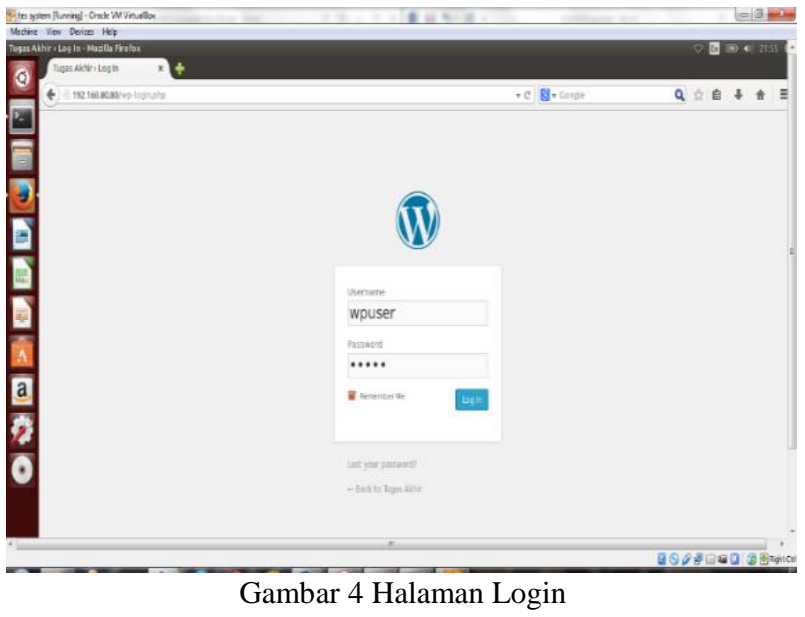

Pada gambar 4 ditunjukkan bahwa wordpress telah dapat diakses melalui ip dari HAProxy dengan permintaan 192.168.80.80/wp-admin sehingga menampilkan halaman login pada wordpress. 


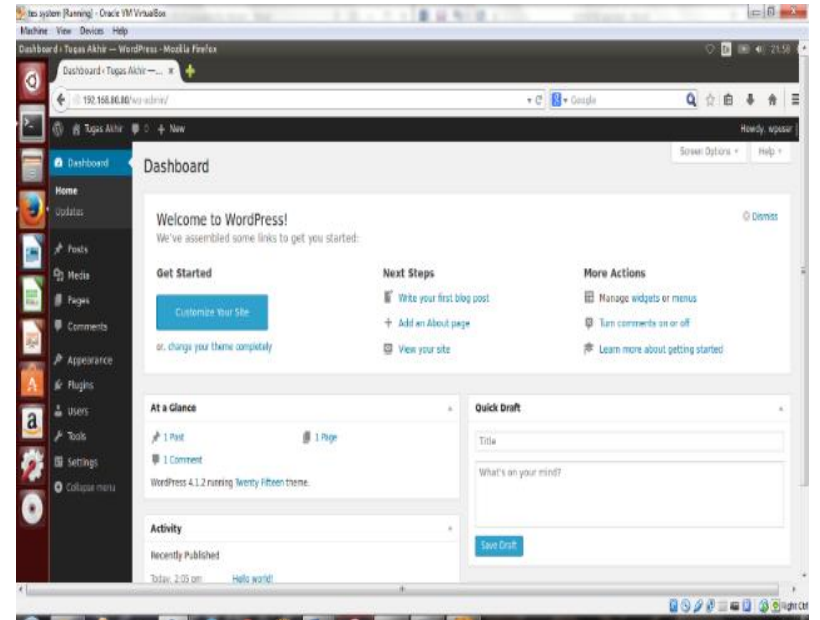

Gambar 5 Halaman Setelah Berhasil Login

User berhasil login seperti yang di tunjukkan pada gambar 5. User berhasil login setelah memasukkan login pada alamat 192.168.80.80/wp-admin.

Pada penginstalan MySQL Cluster, berbeda dengan mysql server dan mysql client yang akan meminta pembuatan password untuk mengakses root. Pada pembuatannya hal tersebut tidak diminta oleh kluster.

Setelah node ndbd dijalankan dikedua node, maka teknologi MySQL Cluster sudah berjalan dengan lancar. Lakukan pengecekan pada manajemen client di NDB_MGM. Berikut adalah tampilannya.

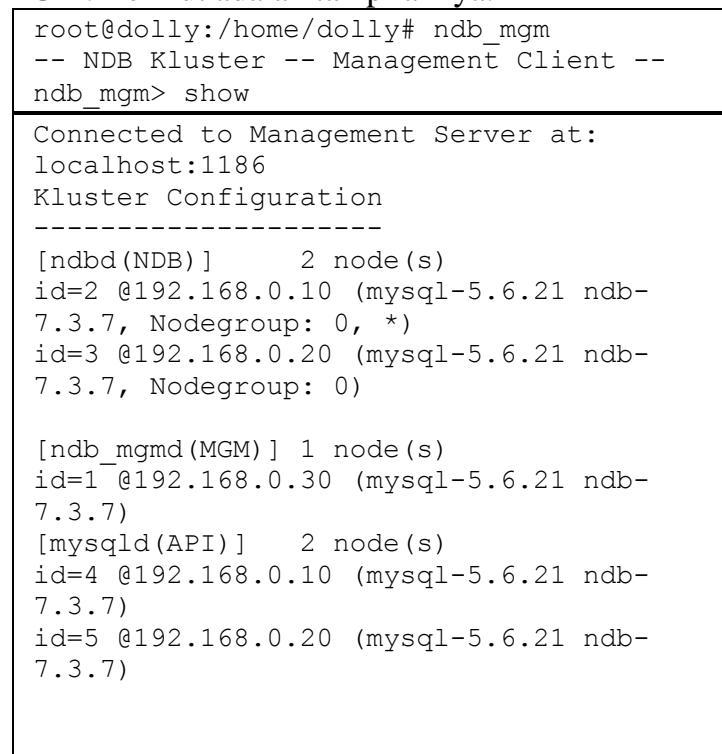

Masuk ke mysql untuk mengetahui apakah ndb kluster sudah aktif. Berikut cara mengetahui mesin ndb kluster telah aktif.

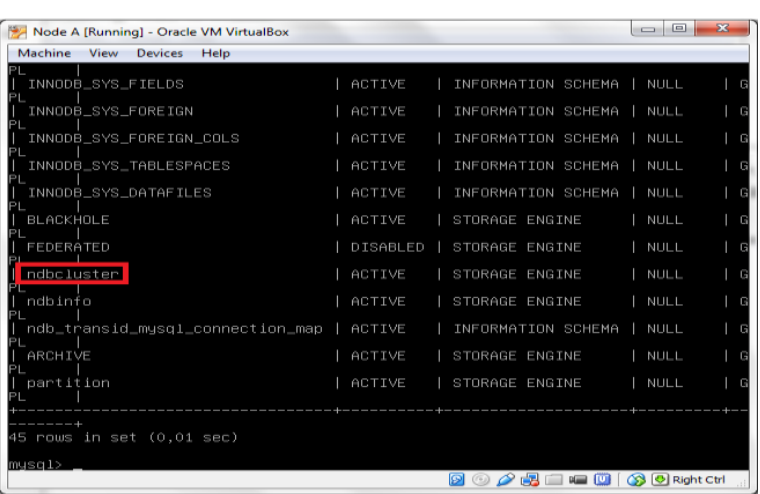

Gambar 6 NDB Kluster Telah Aktif

Pada gambar 6 dapat diketahui bahwa engine ndbcluster sudah aktif dengan berbagai keterangannya. Setelah engine ndbcluster sudah siap, lakukan pengujian yang akan mencoba apakah kluster sudah benar-benar berjalan dengan baik.

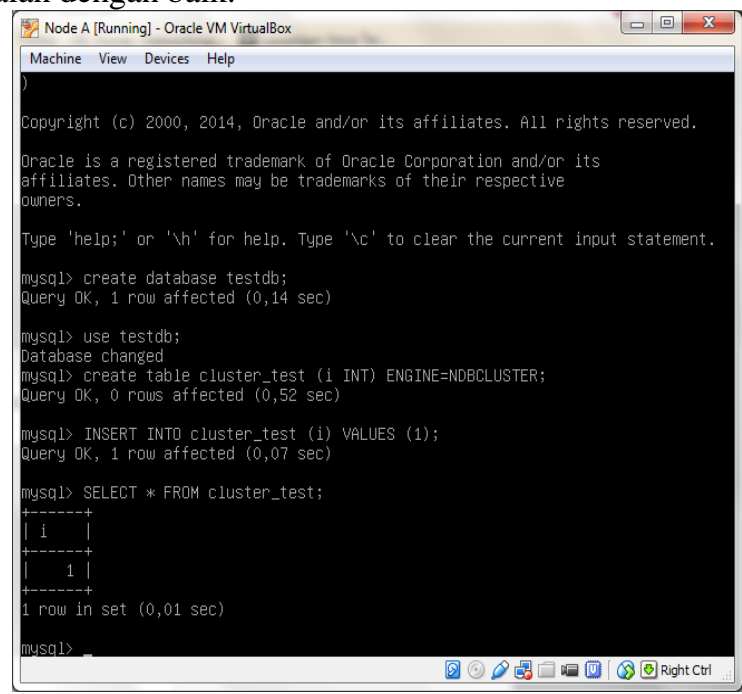

Gambar 7 Tampilan Pengujian Replikasi Node A

Pengujian yang dilakukan untuk melihat perubahan data pada basisdata kluster sudah berjalan dengan semestinya. Replikasi yang digunakan pada server basidata menggunakan replikasi satu arah master to slave. Replikasi master to slave memungkinkan perubahan yang dilakukan pada Node A juga berdampak pada Node B secara otomatis dan sebaliknya. Pada gambar 7 di tunjukkan tampilan data pada Node A. Pada gambar 8 di tunjukkan tampilan data yang sama seperti yang terdapat pada Node A. Hal ini membuktikan bahwa replikasi pada ndbcluster ini telah berjalan dengan sempurna. 


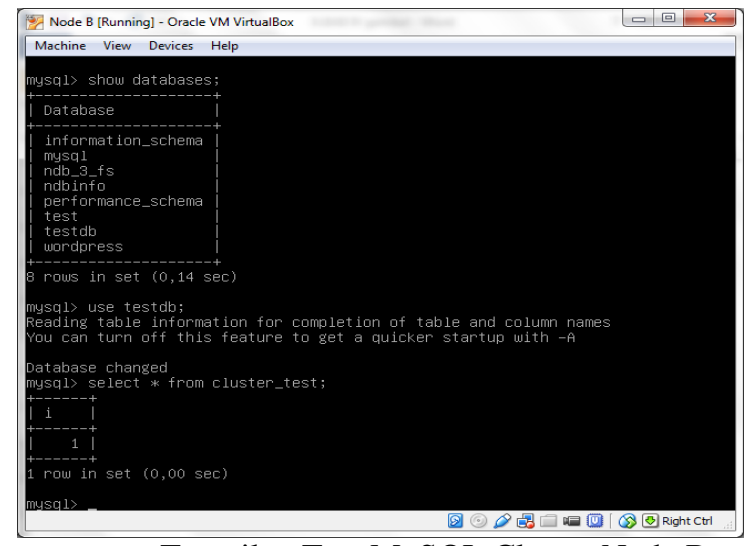

Gambar 8 Tampilan Test MySQL Cluster Node B

Jika replikasi pada Node A dan Node B sudah terjalin, maka teknologi pada MySQL Cluster sudah berjalan dengan baik.

Setelah dipastikan bahwa server MySQL Cluster sudah berjalan maka akan dicoba sifat MySQL Cluster yaitu high availability. Pertama-tama yang akan dibuat sebuah database. Database yang akan dibuat adalah Province. Dengan tabel city dan subdistrict.

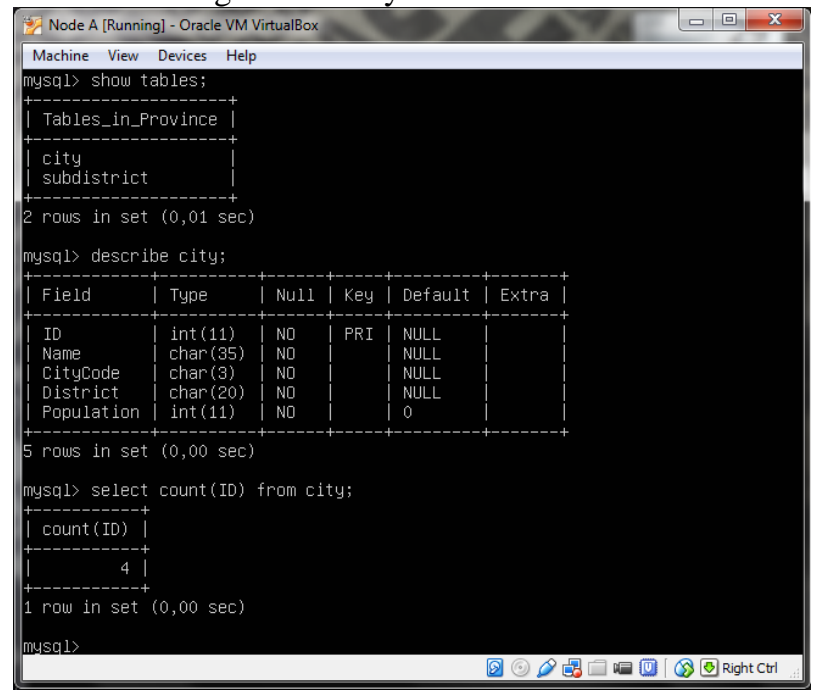

Gambar 9 Pengecekan Jumlah ID Pada Node A

Dapat dilihat pada gambar 9 bahwa isi dari tabel city ada 4 id. Nilai id itu akan menjadi patokan apakah sifat high availability dapat berjalan dengan sempurna. Untuk itu kita harus mematikan node ndbd pada sisi slave.

[roote localhost ] \# killall ndbd

Bisa dilihat pada ndb_mgm server apakah node ndbd sudah tidak aktif.

rootedolly:/home/dolly\# ndb_mgm
-- NDB Kluster -- Management Client --
ndb_mgm> show
Connected to Management Server at:
localhost:1186
Kluster Configuration
-----------------
[ndbd(NDB) ] $\quad 2$ node (s)

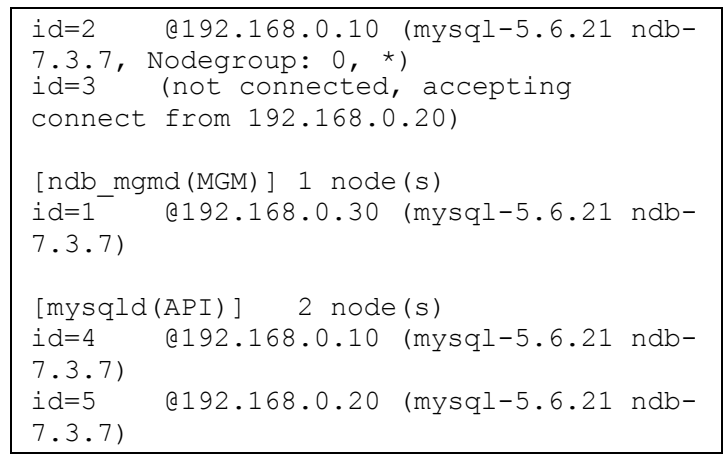

Pada pemberitahuan tersebut dapat diketahui bahwa Node B sudah tidak aktif lagi.

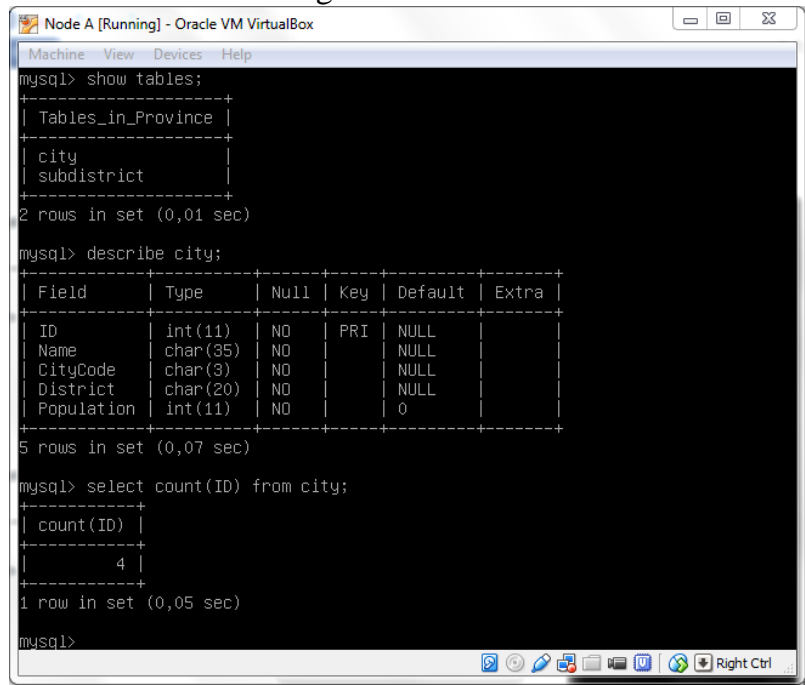

Gambar 10 MySQL Cluster Memiliki Sifat High Availability

Pada gambar 10 dapat diketahui bahwa ID yang terdapat pada basisdata tetap berjumlah 4. Maka MySQL Cluster yang telah dibuat memiliki sifat high availability.

Pengujian webench dengan menggunakan httperf diperlukan untuk mendapatkan hasil berupa data pebandingan serta masukkan seberapa besar performa yang dimiliki oleh sebuah server.

Tabel 1 Hasil pengujian Httperf

\begin{tabular}{|c|c|c|c|l|l|}
\hline $\begin{array}{l}\text { Conne } \\
\text { ction }\end{array}$ & $\begin{array}{l}\text { Conne } \\
\text { ction } \\
\text { Rate }\end{array}$ & $\begin{array}{l}\text { Connc } \\
\text { urrent } \\
\text { Conne } \\
\text { ctions }\end{array}$ & $\begin{array}{l}\text { Reque } \\
\text { st } \\
\text { Rate(r } \\
\text { eq) }\end{array}$ & $\begin{array}{l}\text { Reply } \\
\text { Rate(r } \\
\text { ep/s) }\end{array}$ & $\begin{array}{l}\text { Troug } \\
\text { hput }\end{array}$ \\
\hline 100 & 36.1 & 78 & 24.2 & 20.2 & 250.4 \\
\hline 110 & 35.3 & 84 & 25.3 & 22.4 & 238.6 \\
\hline 120 & 34.1 & 93 & 26.7 & 23.1 & 224.7 \\
\hline 130 & 34.0 & 102 & 25.8 & 24.3 & 213.1 \\
\hline
\end{tabular}




\begin{tabular}{|l|l|l|l|l|l|}
\hline 140 & 33.8 & 113 & 27.4 & 24.8 & 207.6 \\
\hline 150 & 31.9 & 132 & 28.0 & 25.1 & 203.8 \\
\hline 160 & 29.7 & 130 & 28.7 & 24.7 & 210.3 \\
\hline 170 & 28.6 & 148 & 29.3 & 26.4 & 207.8 \\
\hline 180 & 29.7 & 162 & 29.7 & 27.1 & 202.2 \\
\hline 190 & 30.0 & 168 & 30.4 & 24.3 & 192.7 \\
\hline 200 & 29.2 & 177 & 28.6 & 26.8 & 187.9 \\
\hline
\end{tabular}

kemampuan optimal saat server dalam keadaan idle berada diantara 150 - 170 koneksi yang menghasilkan troughput sebesar $203.8-210.3 \mathrm{~KB} / \mathrm{s}$ tanpa adanya permintaan yang error. Node manajemen dirancang untuk melakukan monitoring dan mesin ndbcluster untuk melakukan replikasi diantara 2 server basisdata. Basisdata kluster dengan mesin ndbcluster memiliki keungggulan dalam performansi karena tidak memerlukan piranti lunak tambahan pada implementasinya.

Beberapa saran yang dapat diberikan sehubungan penelitian ini yaitu, rancangan basisdata kluster dapat diimplementasikan pada perangkat fisik dengan

Tabel 1 adalah hasil pengujian saat server up, server yang dirancang masih mampu melayani permintaan sampai 200 koneksi. Kemampuan optimal saat server dalam keadaan idle berada diantara 150 - 170 koneksi yang menghasilkan troughput sebesar $203.8-210.3 \mathrm{~KB} / \mathrm{s}$ tanpa adanya permintaan yang error. Jika server memiliki perangkat yang lebih besar, bukan tidak mungkin server yang dirancang ini mampu melayani permintaan yang lebih banyak.

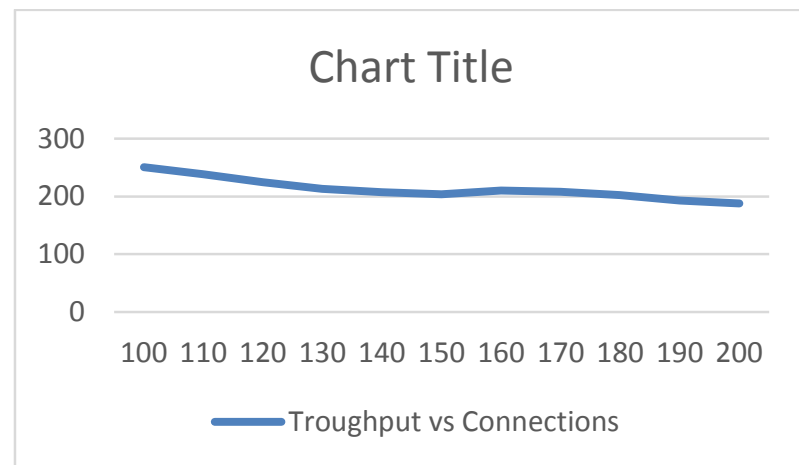

Gambar 11 Grafik Troughput vs. Connections

Grafik hasil dari pengujian koneksi yang diberikan terhadap server dan troughput yang diterima oleh klien menggunakan httperf. Karena menggunakan server tunggal, maka pengujian htterf tidak menggunakan berbagai kondisi. Pada gambar 10 bisa dilihat bahwa hasil uji yang diberikan mesin ndbcluster cenderung lebih stabil dalam memberikan feedback kepada klien. Sinyal troughput yang dikirimkan dengan respon yang diminta juga terlihat stabil, walaupun grafik memperlihatkan performa yang menurun, tetapi masih lebih stabil dibandingkan dengan engine basisdata yang lain.

\section{PENUTUP}

Berdasarkan hasil pengujian dan analisis, dapat diambil beberapa kesimpulan. Basisdata kluster yang diimplementasikan dengan mesin ndbcluster bersifat high availability. Basisdata kluster yang dirancang mampu melakukan replikasi dan pembaharuan data secara realtime. Hasil pengujian menunjukkan bahwa

[6] Hariyanto, D. B. (2007). Sistem Operasi. In D. B. Hariyanto, Sistem Operasi. Informatika

Bandung.

Adelheid, A., \& Nst, K. (2012). BUKU PINTAR menguasai PHP MySQL. In A. Adelheid, \& K. Nst, BUKU PINTAR menguasai PHP MySQL. mediakita.

[2] Charles Bell, M. K. (2010). MySQL High Availability: Tools for Building Robust Data Centers. In M. K. Charles Bell, MySQL High Availability: Tools for Building Robust Data Centers (p. Juni). O’Reilly Media.

[3] Davies, A. (2010). High Availability MySQL Cookbook. In A. Davies, High Availability $M y S Q L$ Cookbook. PACKT.

[4] Ellingwood, J. (2014, April 24). DigitalOcean ${ }^{\mathrm{TM}}$ Inc. Retrieved from How To Install Wordpress on Ubuntu 14.04:

https://www.digitalocean.com/community/tutori als/how-to-install-wordpress-on-ubuntu-14-04

[5] Gultom, H. (2009, Juni 11). mysql-kluster. Retrieved from mysql-kluster: http://henry.gultom.or.id/2009/06/11/membuatmysql-kluster/\#more-286 
[7] Shared nothing kluster vs shared disk kluster. (n.d.). Retrieved from Shared nothing kluster vs shared disk kluster:

http://www.evidian.com/products/highavailability-software-for-applicationklustering/shared-nothing-kluster-vs-shareddisk-kluster/

[8] Stopford, B. (2009, November 24). Shared Nothing v.s. Shared Disk Architectures: An Independent View. Retrieved from Shared Nothing v.s. Shared Disk Architectures: An Independent View:

http://www.benstopford.com/2009/11/24/unders tanding-the-shared-nothing-architecture/

[9] Sumathi, D. S., \& Esakkirajan, S. (2007). Fundamentals of Relational Database Management Systems. In D. S. Sumathi, \& S. Esakkirajan, Fundamentals of Relational Database Management Systems. Springer.

[10] Tarreau, W. (2015, 02 01). HAProxy Configuration Manual. Retrieved from HAProxy Configuration Manual:

http://www.haproxy.org/ 